\title{
Miscellany
}

\section{The McHarg Prize}

The Scottish Division of the Royal College of Psychiatrists offer a prize of $£ 100$ to a trainee who is working in Scotland and who is of senior registrar or registrar grade. Candidates for the prize are invited to submit essays or scientific papers based on their own studies or their original work. It is expected that submissions will range from essays based on literature review to descriptions of clinical work or research in the field.

All entries will be considered by a panel set up by the Scottish Executive Committee and it is intended that the successful candidate will be invited to present his or her paper to a meeting of the Scottish Division.

Submissions must be returned before 1 December 1989 to Dr R. G. McCreadie, Honorary Secretary, Scottish Division, Crichton Royal Hospital, Dumfries, DG1 4TG.

\section{New appointments}

Dr Ashoka Jahnavi Prasad, Consultant Psychiatrist, Claybury Hospital, Woodford Green, Essex has been appointed Professor of Psychiatry at St Mary's University, Halifax, Canada and will be taking up his appointment in April 1990.

Marjorie Wallace, formerly a campaigning journalist with Times Newspapers, has been appointed
Director of SANE (Schizophrenia: A National Emergency).

\section{Neuroscience research centre}

Construction of the Edward Robinson/MRC Pharmacology Building at Oxford began recently. In October 1987 the Squibb Corporation entered a long-term agreement with Oxford University to fund the establishment of a research facility for the Department of Pharmacology and to endow the facility's operating costs. In addition, Squibb agreed to fund individual neuroscience projects proposed by the Department in areas such as degenerative diseases of the central nervous system.

\section{London flat to rent}

A flat in Hampstead will be available to a visiting faculty member or other professional person from 25 September 1989 until early July 1990 at a rent of $£ 600$ per month, exclusive of utilities; non-smoker preferred. The flat has one bedroom, sitting room, central heating, and all modern conveniences. The tenant would have use of the garden which opens onto the woods of the Heath. Please apply to: Dr Deborah Weiner, 2537 Overhill Lane, Davis, California 95616, USA (telephone 9167531004 or 916753 9051).

\section{Forthcoming events}

The Royal Society of Medicine will be holding the next meeting of the Forum on Clinical Pharmacology and Therapeutics entitled 'The Anxiolytic Jungle: Where Next?' on 6 October 1989. Registration fees: £35 (non-members); $£ 25$ (members) - to include coffee, lunch and tea. The meeting has Section 63 approval. Further information: Nicole Aaron, The Royal Society of Medicine, 1 Wimpole Street, London W1M 8AE(telephone 014082119 , extension 301).

A study day entitled 'The Mind Body Problem' exploring the interface between psychotherapy and physical medicine is to be held at the Freudenberg
Postgraduate Medical Centre, Netherne Hospital on 12 October 1989. Contributors will include the Medical Director of the Bristol Cancer Centre. For information sheet and further details: The Secretary to Dr I. F. Macilwain, Netherne Hospital, PO Box 150, Coulsdon, Surrey CR3 1YE.

A conference entitled 'Practical Approaches to Alcohol and Ofiending: Politics, Policy \& Prevention' will be held at Leicester Polytechnic from 14-15 September 1989. Fees: $£ 125$ full rate; $£ 95$ students and voluntary. agencies (includes refreshments, meals and accommodation). Further information: Alcohol \& Offending Conference, 20 College Avenue, Leicester LE2 0JF. 